\title{
A Reputational Study of Academic Publishers
}

\section{Paul Metz and John Stemmer}

In both selecting individual titles and designing gathering plans, collection development librarians are strongly influenced by the perceptions they have about publishers. In the near absence of data that might indicate the overall perceptions the collection development community has about academic publishers, the authors distributed a reputational assessment survey to a national sample of heads of collection development in academic libraries. The resulting data on perceptions of the quality and academic relevance of selected publishers' monographs are reported and analyzed.

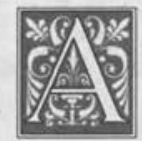

lthough the selection of books is only one among the increasingly long and varied list of functions that make up collection development, it is still, to a considerable degree, the defining task of collection development. The image of a bibliographer alone in an office cluttered with reviews, approval slips, publisher flyers, catalogs, and bibliographies remains a paradigm of the collection development craft. The importance of book selection is much more than symbolic. Despite the documented increase in the serials component of research libraries' materials budgets and despite the growth in electronic databases, online services, and video and document-delivery services that compete with books for collections budgets, college and university libraries still spend hundreds of millions of dollars annually on books.
Each book acquired by an academic library represents the outcome of a decision. Often the decision will be a micro one: this book by this author is the right book for us to acquire in support of our programs. Often, and increasingly, the book will be chosen consequent to a macro decision, such as the addition of a publisher or subject area to an approval plan profile or the initiation of a blanket order or membership. ${ }^{1}$

In both the macro and micro decisions that build monographic collections, a few criteria are generally decisive. Leaving aside ancillary criteria such as the book's relationship to the existing collection, the three overriding issues generally are the relevance of the book to the institution's mission and goals; the presumed quality of the book; and, given the desirability of the title on these dimensions, its price and the question of whether the selection

Paul Metz is Principal Bibliographer, University Libraries, Virginia Polytechnic Institute and State University-Blacksburg; e-mail: pmetz@vt.edu. John Stemmer is Collegiate Librarian for Arts and Sciences, University Libraries, Virginia Polytechnic Institute and State University-Blacksburg; e-mail: jstemmer@vt.edu. 
would represent an efficient expenditure of the library's limited resources.

It is important to recognize that in the great majority of cases, it is not the book itself but some surrogate that is being assessed against these criteria. If the bibliographer is lucky, the surrogate will be a thoughtful review in a trusted source such as the New York Times Book Review at the time of the book's publication. Far more often, the surrogate will be an extract of basic cataloging information encountered on a decision slip or in The American Book Publishing Record.

Relevance and quality in this case must be assessed in highly constrained and subjective ways. This calls for an on-thespot exercise of experienced judgment within highly bounded rationality. ${ }^{2}$ The book's title, the subject scope typically associated with the publisher, and, on occasion, some knowledge about the author have to serve as the basis for relevance judgments. There is even less basis for imputing quality, because in this respect the title is rarely helpful.

Because even the best bibliographers can be expected to be familiar with only a minority of authors in their fields, and because titles provide limited information, knowledge of the publisher often furnishes the decisive element in selection decisions. Unfortunately, this consideration raises the further nonobvious question of how much bibliographers know about publishers, how they acquire that knowledge, and how much confidence they can have in their judgments. It is likely that most bibliographers' impressions of most publishers represent an amalgam of conscious conclusions and much more visceral impressions that have been gathered over years of academic training, personal reading, discussions with academic faculty and other librarians, inspection of library receipts, and use of book reviews.

If bibliographers look to the library literature for guidance on this topic, they will find little beyond two articles, the second a ten-year replication and expansion of the first. John Calhoun and James K. Bracken's brief 1983 Research Notes in College $\&$ Research Libraries reported the number of titles, number of outstanding book awards, and the ratio of awards to titles for the sixty publishers most often winning Choice Outstanding Academic Book awards (OABs) for the years 19771981. Calhoun and Bracken made their data easily interpretable by normalizing the ratios to a fixed benchmark of 1.0 , representing a ratio of awards to titles equivalent to the proportion of awards won by the "Oxbridge" (Oxford and Cambridge) university presses. Of their sixty publishers, twenty were university presses. $^{3}$

In 1993, Edward Goedeken published a partial replication of Calhoun and Bracken's study, based on Choice data for the years 1988-1992. He also listed the then prevailing top sixty $\mathrm{OAB}$ publish-

\section{Because even the best bibliographers can be expected to be familiar with only a minority of authors in their fields, ... knowledge of the pub- lisher often furnishes the decisive element in selection decisions.}

ers. The university press component had, by 1993 , grown to twenty-seven presses, which accounted for 48 percent of awards, up from 33 percent for the ten-year period of the first study. In his discussion, Goedeken made the unsurprising observation that Calhoun and Bracken's assertion that their ratios represented "a measurement of publisher quality" had generated controversy based, in part, on the validity of comparisons between the book lists of university presses and trade publishers. ${ }^{4}$

Although relevance and quality are plainly subjective attributes about which no one would expect to find scientifically validated or conclusive data, the importance to librarians of having some reliable 
basis for publisher judgments contrasts strikingly with the paucity of any sort of information on the topic. The authors conceived the present study to address this problem.

\section{Methodological Issues}

This study takes as its premise that both the subject scope that might be associated with a given publisher and the quality that might be attributed to its books represent inherently subjective judgments (which is no more than might be said of book reviews or book awards). It follows that the best way to study the topic is to admit this constraint up front and to attempt to assess as directly as possible the perceptions and opinions of informed observers.

From a library point of view, a logical set of observers would be heads of collection development, and so a reputational survey was sent to these individuals. To capture the range of higher education and the variety of collection development practices, the authors defined the universe of potential respondents as the chief collection development officers at all ARL member institutions, and at the Oberlin group (Obergroup) institutions, which comprise seventy-two liberal arts colleges in the United States.

The nominal heads of collection development at ARL libraries and the directors at Obergroup institutions seemed to be the most likely respondents, but the wide variety of organizational schemes and job titles makes it difficult in many cases to identify this person. Accordingly, respondents were given the following instructions so that the questionnaire could be referred at each institution to the person most able to respond:

Before completing the survey, please take a minute to make sure you are the appropriate respondent, according to the following definition:

The respondent should be the librarian most intimately respon- sible for building the library collection in all areas.

- In ARL libraries, this will often be an associate or assistant director. However, if such an individual's duties combine collection development and other major functional areas, and if there exists a fulltime subordinate responsible for collection development in all areas, the latter should respond.

- In the Oberlin group, each director should designate the individual (potentially her- or himself) most responsible for overall collection development.

If you do not match this definition, please forward the questionnaire to the appropriate respondent for your library. Several respondents to our first mailing noted that they found it necessary to consult with colleagues more familiar than themselves with certain publishers or disciplines. This is fine, though we ask that one person attempt to ensure consistent application of the ranking scales.

The final two sentences of the instructions were included only in the followup, but were consistent with advice the authors had given in response to inquiries from first-round respondents.

After some reflection, and with mixed advice, the authors decided to ask respondents to report their perceptions on the relevance of each publisher's output to local collecting programs and on publisher quality, but not price. The rationale for this exclusion rested on several considerations. To ask about more parameters logically would require a reduction in the number of publishers that could be included within a limited imposition on the respondents' time and courtesy. Accepting this constraint, the authors decided to focus on the two dimensions for which there are, and can be, no objective data. Price can generally be determined 
on an individual title basis from the notice that generates the original order, and on the macro basis, it can generally be assessed on a per publisher basis from approval vendors' reports and controlled by dollar limitations on automatic book receipt within the parameters of a vendor profile.

The remaining basic decision, after the respondent universe and the key questions to ask had been determined, was which publishers to include. A broad representation of the varying types of academically relevant publishers, with inclusion of the larger houses, seemed ideal. The actual selection was based on the following criteria:

- So that the larger houses would be included regardless of academic orientation, the top twenty publishers in book volume as measured by the spring 1994 edition of Yankee Book Peddler's "annual roundup" of publisher data were included.

- To assess all university presses would place undue emphasis on this publishing group, especially because it is often the trade publishers about whom selectors have the most questions. But the authors did want to see how, in the perception of collection development officers, the range of university presses and the range of academic publishers would compare when superimposed. Accordingly, the authors selected six university presses: Oxford and Cambridge because of their reputations, high volume, and previous use as benchmark publishers in the OAB studies; Harvard and Stanford to represent the elite of American university presses; and SUNY and Oklahoma to represent the general body of American university presses.

- The authors selected other publishers representing important houses associated with science and technology, the humani- ties, or the social sciences. Most of these were well established and well known, but the New Press was included partly out of curiosity about whether collection officers would be able to report their perceptions about it.

- The authors included a few publishers on the basis of their awareness that these publishers were either controversial or the focus of strong opinions within the collection development community.

Given the exclusion of price, the three categories about which respondents were asked to indicate their perceptions of each publisher were familiarity, relevance, and quality. The first, familiarity, was of interest in that one would like to know which publishers are best known to the collection development community. The question was also asked to make it possible to ensure that the opinions of only those individuals who had some knowledge, even if self-reported, were considered in evaluating a publisher. The other two factors, relevance and quality, were the major variables of substantive interest in the study. The definitions used in the questionnaire, as defined in the instrument itself, were:

Familiarity: The degree (little/none, moderate, high) to which you feel famil-

\section{TABLE 1}

Distribution of Respondents' Titles

24.4\% Collection Development Librarian

14.2 Library Director

13.4 Associate Director for Collection Development

8.7 Collection Development Coordinator

7.1 Acquisitions Librarian

4.7 Acquisitions/Collection Development Librarian

2.4 Technical Services/Collection Development Librarian

1.6 Head of Reference \& Chair of Collection Development Committee

0.8 Assistant Head of Public Services for BI \& Collection Development

22.8 Miscellaneous titles 


\begin{tabular}{|cl|}
\hline \multicolumn{1}{|c|}{ TABLE 2 } \\
Distribution of Supervisors' Titles \\
\hline \hline $61.1 \%$ & Library Director \\
11.1 & Provost \\
4.0 & Assistant Director for Technical \\
& Services \& Collection Management \\
4.0 & Associate University Librarian for \\
& Public Services \& Collection \\
& Development \\
2.4 & Associate Dean for Collections \& \\
& Services \\
2.4 & Associate Director \\
2.4 & Director for Collection Development \\
12.7 & Miscellaneous titles \\
\hline
\end{tabular}

iar with a publisher and capable of commenting on its books. Please skip the remaining two questions for any publisher for which you rate your familiarity as little/none. (In the actual analysis all relevance and quality scores for respondents who reported little or no familiarity for a publisher but who disregarded this instruction were converted to N/A).

Relevance: The degree to which a publisher's book titles address topics of interest to the academic community and the extent to which established modes of scholarly or scientific discourse guide the presentation of material.

Quality: The overall intellectual and editorial quality of a publisher's monographic offerings, reflecting the expertise of typical authors; the persuasiveness of evidence; the intellectual level of discourse; the tendency of a publisher's titles to be influential in their fields; and the degree of editorial care.

The questionnaire offered respondents a five-point Likert scale ranging from "very low" to "very high" for responses on the relevance and quality items. The total response rate to the questionnaire was 70.7 percent, yielding a total of 128 usable responses. The replies were in response to two waves of the survey, the first on November 1, 1994, with follow-up to initial nonrespondents on
January 15,1995 . The ARL response rate was about 67 percent and that of the Obergroup was 75 percent. The responding institutions came from all over the United States and Canada.

The authors gathered a certain amount of institutional information (such as affiliation [public or private], materials budget, Barron's selectivity rating, and whether each institution offered the doctorate in English, electrical engineering, both, or neither) from various reports and reference sources. Comparing responding to nonresponding institutions on these parameters, the authors found no response bias, even at a criterion of $\mathrm{p}<.20$.

The survey devoted a number of questionnaire items to basic background information about the respondents themselves and their supervisors. To determine the experience level of the respondents, they were asked how many years they had been in collection development and in their current positions. Those who answered the survey had an average of a little over 16.5 years in collection development. The average length of time in their current position was 7.2 years. Table 1 reports the most frequent titles of respondents. As indicated in table 2, the great majority of respondents reported to library directors or other senior librarians.

\begin{tabular}{|rl|}
\hline & \multicolumn{1}{c|}{$\begin{array}{c}\text { TABLE 3 } \\
\text { Educational Attainment } \\
\text { of Respondents }\end{array}$} \\
\hline \hline & Master's degree in library science \\
$96.0 \%$ & Master's in a humanities field \\
32.0 & Master's in a social sciences field \\
17.2 & Master's in a sciences field \\
3.1 & Professional degree \\
5.5 & Ph.D. in a humanities field \\
13.3 & Ph.D. in a social sciences field \\
4.7 & Ph.D. in a sciences field \\
0.8 & Ed.D. \\
1.6 & \\
\hline
\end{tabular}




\begin{tabular}{|c|c|c|c|c|c|}
\hline \multicolumn{6}{|c|}{$\begin{array}{l}\text { TABLE 4 } \\
\text { Perceptions of Academic Publisher Familiarity, Relevance, and Quality }\end{array}$} \\
\hline Publisher & Familiarity & Publisher & Relevance & Publisher & Quality \\
\hline Cambridge & 2.96 & Cambridge & 4.83 & Harvard & 4.82 \\
\hline Oxford & 2.94 & Harvard & 4.82 & Cambridge & 4.80 \\
\hline Gale & 2.89 & Oxford & 4.81 & Oxford & 4.77 \\
\hline Harvard & 2.87 & Stanford & 4.60 & Stanford & 4.51 \\
\hline Garland & 2.80 & National Acad. & 4.52 & National Acad. & 4.44 \\
\hline Routledge & 2.76 & Elsevier & 4.47 & Brookings & 4.37 \\
\hline Blackwell & 2.75 & Springer-Verlag & 4.46 & Springer-Verlag & 4.34 \\
\hline Greenwood & 2.75 & Brookings & 4.41 & Blackwell & 4.25 \\
\hline St. Martins & 2.74 & CRC & 4.38 & Smithsonian & 4.24 \\
\hline Random House & 2.72 & Blackwell & 4.37 & Elsevier & 4.15 \\
\hline Knopf & 2.70 & Kluwer & 4.30 & Wiley & 4.15 \\
\hline Simon \& Schuster & 2.69 & Wiley & 4.26 & CRC & 4.08 \\
\hline Stanford & 2.67 & SUNY & 4.24 & Kluwer & 4.07 \\
\hline McGraw-Hill & 2.67 & Academic & 4.22 & Academic & 4.03 \\
\hline Wiley & 2.66 & Routledge & 4.17 & Oklahoma & 4.00 \\
\hline Macmillan & 2.66 & Sage & 4.12 & Routledge & 3.97 \\
\hline Sage & 2.65 & Greenwood & 4.11 & Knopf & 3.96 \\
\hline Springer-Verlag & 2.64 & Oklahoma & 4.06 & Farrar, Straus & 3.96 \\
\hline Houghton Mifflin & 2.64 & Plenum & 4.05 & Norton & 3.90 \\
\hline Prentice Hall & 2.64 & Gale & 4.01 & Basic & 3.90 \\
\hline Elsevier & 2.63 & Westview & 4.00 & New Directions & 3.90 \\
\hline HarperCollins & 2.63 & $\mathrm{VCH}$ & 3.98 & $\mathrm{VCH}$ & 3.88 \\
\hline Smithsonian & 2.63 & Garland & 3.98 & SUNY & 3.86 \\
\hline Brookings & 2.60 & Erlbaum & 3.95 & Plenum & 3.84 \\
\hline Norton & 2.60 & Humanities & 3.94 & St. Martins & 3.83 \\
\hline Penguin & 2.59 & Jossey-Bass & 3.88 & Allen \& Unwin & 3.81 \\
\hline Praeger & 2.58 & Basic & 3.87 & Free Press & 3.77 \\
\hline Doubleday & 2.57 & Praeger & 3.86 & Sage & 3.77 \\
\hline Free Press & 2.52 & Smithsonian & 3.86 & Erlbaum & 3.76 \\
\hline Haworth & 2.52 & World Scientific & 3.80 & Macmillan & 3.69 \\
\hline UPA & 2.51 & M. Dekker & 3.79 & Praeger & 3.68 \\
\hline Farrar, Straus & 2.51 & St. Martins & 3.77 & New Press & 3.68 \\
\hline Basic & 2.50 & ME Sharpe & 3.76 & Chapman \& Hall & 3.68 \\
\hline Academic & 2.50 & Allen \& Unwin & 3.76 & Penguin & 3.67 \\
\hline Jossey-Bass & 2.48 & Free Press & 3.75 & Jossey-Bass & 3.65 \\
\hline SUNY & 2.48 & Chapman \& Hall & 3.73 & Gale & 3.65 \\
\hline Viking & 2.48 & New Directions & 3.71 & Random House & 3.64 \\
\hline Westview & 2.46 & Transaction & 3.67 & Humanities & 3.62 \\
\hline Oklahoma & 2.33 & Norton & 3.63 & Van Nostrand & 3.62 \\
\hline Plenum & 2.29 & Van Nostrand & 3.58 & Westview & 3.62 \\
\hline CRC & 2.27 & E. Arnold & 3.55 & M. Dekker & 3.61 \\
\hline Kluwer & 2.26 & Macmillan & 3.55 & Atlantic Monthly & 3.60 \\
\hline Addison-Wesley & 2.26 & UPA & 3.55 & Viking & 3.59 \\
\hline E. Mellen & 2.26 & Addison-Wesley & 3.54 & Addison-Wesley & 3.58 \\
\hline National Acad. & 2.21 & New Press & 3.50 & McGraw-Hill & 3.56 \\
\hline \multirow[t]{2}{*}{ Van Nostrand } & 2.21 & Lexington & 3.48 & Transaction & 3.56 \\
\hline & & & & \multicolumn{2}{|c|}{ (Cont. on next page) } \\
\hline
\end{tabular}


TABLE 4 cont.

Perceptions of Academic Publisher Familiarity, Relevance, and Quality

\begin{tabular}{lc|lc|lr}
\hline \hline Publisher & Familiarity & Publisher & Relevance & Publisher & Quality \\
\hline Humanities & 2.19 & Guilford & 3.48 & Houghton Mifflin & 3.55 \\
Times & 2.16 & Ashgate & 3.46 & E. Arnold & 3.51 \\
Atlantic Monthly & 2.13 & Penguin & 3.45 & Greenwood & 3.50 \\
Allen \& Unwin & 2.13 & Knopf & 3.40 & ME Sharpe & 3.49 \\
Erlbaum & 2.10 & McGraw-Hill & 3.40 & Simon \& Schuster & 3.45 \\
ME Sharpe & 2.09 & Farrar, Straus & 3.38 & Prentice Hall & 3.45 \\
New Directions & 2.09 & Prentice Hall & 3.37 & Allyn \& Bacon & 3.41 \\
Transaction & 1.98 & Allyn \& Bacon & 3.34 & HarperCollins & 3.40 \\
Chapman \& Hall & 1.94 & Haworth & 3.34 & Guilford & 3.34 \\
Lexington & 1.91 & Random House & 3.19 & Lexington & 3.28 \\
M. Dekker & 1.90 & Houghton Mifflin & 3.18 & World Scientific & 3.23 \\
Allyn \& Bacon & 1.76 & Viking & 3.18 & Ashgate & 3.22 \\
E. Arnold & 1.65 & Atlantic Monthly & 3.11 & Garland & 3.21 \\
Guilford & 1.61 & Simon \& Schuster & 3.10 & Times & 3.10 \\
VCH & 1.56 & HarperCollins & 3.08 & Doubleday & 3.00 \\
World Scientific & 1.55 & E. Mellen & 2.93 & UPA & 2.91 \\
Ashgate & 1.48 & Times & 2.64 & Haworth & 2.65 \\
New Press & 1.44 & Doubleday & 2.48 & E. Mellen & 1.96 \\
\hline
\end{tabular}

The survey also requested the number of advanced degrees held by the respondents and the broad fields of those degrees (science, humanities, social science). Virtually all respondents possessed a library degree. Most had gone on to earn a second advanced degree, most often in humanities fields. A significant percent-

Correlations between familiarity and relevance were positive for all publishers.

age had gone on to earn a higher terminal degree, again the vast majority being in humanities fields. Table 3 reports the respondents' various levels of educational attainment.

\section{Major Findings}

Tables 4 and 5 present the scores for each of the publishers listed in the survey. In interpreting these scores, it is important to remember that they are reputational. They are not based on any quantifiable data but, rather, on collection development librarians' collective opinions. ${ }^{5}$

From both a methodological and a substantive point of view, it was necessary to determine the relationships among the three key measures being assessed in the study. The correlations among observed familiarity, relevance, and quality were almost always positive. Table 6 shows the mean correlation over publishers among the three dependent measures. All correlations reported in this study are Pearson product-moment correlations.

Correlations between familiarity and relevance were positive for all publishers. Correlations of slightly over .50 were obtained for Ashgate, Basic Books, Elsevier, Kluwer, New Directions, and $\mathrm{VCH}$. In other words, for all publishers, perceptions of academic relevance were a positive function of familiarity, more so for the indicated publishers than for others.

Nearly all correlations between familiarity and quality were positive, with correlations exceeding .50 for Ashgate, 
Elsevier, National Academy of Science, and New Directions. Three small negative correlations were found between familiarity and perceived quality, with the -.12 correlation for Mellen being the largest.

The correlation between measures of relevance and quality suggests a serious "halo effect." Only in five cases did the correlation between these measures for specific publishers not exceed .50. Perhaps it could be argued that publishers with a more scholarly or scientific profile invest more care in their books, or can make a profit publishing only their strongest manuscripts, and that therefore the relationship between academic relevance and quality represents reality on some level. However, it also seems only realistic to concede that a halo effect does exist between respondents' perceptions of these two dimensions.

Despite the halo effect between perceptions of relevance and quality, there were a number of publishers for whom perceptions on the two dimensions differed in dramatic and revealing ways. Looking only at publishers whose rank orders on the two dimensions differed by fifteen or more places, the authors found two rather different groupings. For Gale, Garland, Greenwood, Sharpe, University Press of America, Westview, and World Scientific, rankings for relevance were at least fifteen places greater than those for quality. To some degree, these publishers target the academic library marketplace, giving their imprints a scope that is relevant almost by definition.

The opposite finding, rankings of fifteen or more
TABLE 5

Perceptions of Academic Publisher Familiarity, Relevance, and Quality (alpha order)

\begin{tabular}{lccc} 
Publisher & Familiarity & Relevance & Quality \\
\hline Academic & 2.50 & 4.22 & 4.03 \\
Addison-Wesley & 2.26 & 3.54 & 3.58 \\
Allen \& Unwin & 2.13 & 3.76 & 3.81 \\
Allyn \& Bacon & 1.76 & 3.34 & 3.41 \\
Ashgate & 1.48 & 3.46 & 3.22 \\
Atlantic Monthly & 2.13 & 3.11 & 3.60 \\
Basic & 2.50 & 3.87 & 3.90 \\
Blackwell & 2.75 & 4.37 & 4.25 \\
Brookings & 2.60 & 4.41 & 4.37 \\
Cambridge & 2.96 & 4.83 & 4.80 \\
Chapman \& Hall & 1.94 & 3.73 & 3.68 \\
CRC & 2.27 & 4.38 & 4.08 \\
Doubleday & 2.57 & 2.48 & 3.00 \\
E. Arnold & 1.65 & 3.55 & 3.51 \\
E. Mellen & 2.26 & 2.93 & 1.96 \\
Elsevier & 2.63 & 4.47 & 4.15 \\
Erlbaum & 2.10 & 3.95 & 3.76 \\
Farrar, Straus & 2.51 & 3.38 & 3.96 \\
Free Press & 2.52 & 3.75 & 3.77 \\
Gale & 2.89 & 4.01 & 3.65 \\
Garland & 2.80 & 3.98 & 3.21 \\
Greenwood & 2.75 & 4.11 & 3.50 \\
Guilford & 1.61 & 3.48 & 3.34 \\
HarperCollins & 2.63 & 3.08 & 3.40 \\
Harvard & 2.87 & 4.82 & 4.82 \\
Haworth & 2.52 & 3.34 & 2.65 \\
Houghton Mifflin & 2.64 & 3.18 & 3.55 \\
Humanities & 2.19 & 3.94 & 3.62 \\
Jossey-Bass & 2.48 & 3.88 & 3.65 \\
Kluwer & 2.26 & 4.30 & 4.07 \\
Knopf & 2.70 & 3.40 & 3.96 \\
Lexington & 1.91 & 3.48 & 3.28 \\
M. Dekker & 1.90 & 3.79 & 3.61 \\
Macmillan & 2.66 & 3.55 & 3.69 \\
McGraw-Hill & 2.67 & 3.40 & 3.56 \\
ME Sharpe & 2.09 & 3.76 & 3.49 \\
National Acad. & 2.21 & 4.52 & 4.44 \\
New Directions & 2.09 & 3.71 & 3.90 \\
New Press & 1.44 & 3.50 & 3.68 \\
Norton & 2.60 & 3.63 & 3.90 \\
Oklahoma & 2.33 & 4.06 & 4.00 \\
Oxford & 2.94 & 4.81 & 4.77 \\
Penguin & 2.59 & 3.45 & 3.67 \\
Plenum & 2.29 & 4.05 & 3.84 \\
& & $($ Cont. on next page) \\
\hline
\end{tabular}


TABLE 5 cont.

Perceptions of Academic Publisher Familiarity, Relevance, and Quality (alpha order)

\begin{tabular}{lccc|} 
Publisher & Familiarity & Relevance & Quality \\
\hline Praeger & 2.58 & 3.86 & 3.68 \\
Prentice Hall & 2.64 & 3.37 & 3.45 \\
Random House & 2.72 & 3.19 & 3.64 \\
Routledge & 2.76 & 4.17 & 3.97 \\
Sage & 2.65 & 4.12 & 3.77 \\
Simon \& Schuster & 2.69 & 3.10 & 3.45 \\
Smithsonian & 2.63 & 3.86 & 4.24 \\
Springer-Verlag & 2.64 & 4.46 & 4.34 \\
St. Martins & 2.74 & 3.77 & 3.83 \\
Stanford & 2.67 & 4.60 & 4.51 \\
SUNY & 2.48 & 4.24 & 3.86 \\
Times & 2.16 & 2.64 & 3.10 \\
Transaction & 1.98 & 3.67 & 3.56 \\
UPA & 2.51 & 3.55 & 2.91 \\
Van Nostrand & 2.21 & 3.58 & 3.62 \\
VCH & 1.56 & 3.98 & 3.88 \\
Viking & 2.48 & 3.18 & 3.59 \\
Westview & 2.46 & 4.00 & 3.62 \\
Wiley & 2.66 & 4.26 & 4.15 \\
World Scientific & 1.55 & 3.80 & 3.23 \\
\hline
\end{tabular}

$<.01)$ indicated relationships of some interest, but no general pattern.

Most of the statistically significant relationships between given institutional or individual variables and reported perceptions were unsurprising, and consistent with intuition. For example, chief bibliographers at libraries whose parent institutions offer doctorates in electrical engineering are more familiar with Elsevier. Edwin Mellen is more familiar to librarians in institutions with larger materials budgets. Both the relevance and quality attributed to Allen \& Unwin were higher where the doctorate in English is offered. A consistently strong finding was that more experienced collection development heads and those at larger and more selective institutions had higher regard for both the relevance and the quality of imprints from the New Press. Respondents' experience in collection development was positively associated with the perceived relevance of books from $\mathrm{Ba}$ sic Books, the Free Press, Guilford, and Knopf.

It would be inappropriate to make much of these isolated findings, which were found in a purely post hoc "data dredge" of many possible relationships. Indeed, the major conclusion to be drawn is that the perceptions of chief collection development officers seemed to be drawn from a fairly homogeneous pool. There

One of the more interesting findings encountered-perhaps more accurately a "nonfinding" - was the relative weakness of most relationships between either institutional or individual variables and assessments of familiarity, quality, and relevance. Isolated findings of moderately high correlation (.35 or greater, all with $p$

\begin{tabular}{|lcccc|}
\hline \multicolumn{5}{|c|}{$\begin{array}{c}\text { TABLE 6 } \\
\text { Descriptive Statistics for Within-Publisher } \\
\text { Correlation Coefficients, } \mathbf{N = 6 4}\end{array}$} \\
\hline \hline Coefficient & Mean & S.D. & Maximum & Minimum \\
\hline r relevance, quality & .65 & .09 & .87 & .44 \\
r relevance, familiarity & .32 & .12 & .54 & .02 \\
r familiarity, quality & .27 & .15 & .55 & -.12 \\
\hline
\end{tabular}


are no important differences between the perceptions of librarians at large and small institutions, or between those of more or less experienced bibliographers.

To test further the apparent homogeneity of the respondent pool relative to perceptions about publishers, the authors conducted a separate analysis of the perceptions of a subset of respondents who might be considered likely to be more knowledgeable than their peers. Relevance and quality ratings were studied for respondents who had been in collection development for at least five years, at least two of them as head, and whose materials budgets were at least $\$ 1$ million. The authors included scores for only those publishers for whom these individuals had reported high familiarity. With only the most trivial exceptions, the relevance and quality ratings from this "informed elite" for each publisher were indistinguishable from the scores reported in table 4, again confirming the lack of differentiation among the respondent populations.

In many respects, the overall results of this study are self-evident and speak clearly from tables 4 and 5 . The continuum of perceived relevance ranges from Cambridge down to Doubleday, that of perceived quality ranges from Harvard down to Mellen, and every reader of this report is equally free to form an opinion about the credibility or relevance of the findings. The authors suspect that these findings, without complex analysis, will be the chief object of interest in this study.

Notwithstanding the simplicity of the data arrayed in tables 4 and 5, some elements of these findings merit discussion. It is worth noting that although all familiarity scores and the heart of the relevance and quality scores are smoothly distributed, there are some discontinuities. Relevance scores have a fairly significant drop after Cambridge, Harvard, and Oxford, and fall off again at the end where Times and Doubleday are seen as significantly less relevant than the publishers above them. Similarly, quality scores fall off after the same three publishers, and then at the low end Haworth is seen as significantly inferior to the publisher above it, while the further drop from Haworth to Mellen is precipitous. In Mellen's case, the quantitative data were supplemented by a number of pointedly negative comments written by respondents.

The data also provide an answer to the authors' curiosity about how university presses as a whole would be compared to other publishers. For both relevance and quality, ratings begin with the same four exemplary university presses. No university press is rated lower than eighteenth in relevance, and none is lower than twenty-third in quality. Interestingly, of the top ten publishers in both relevance and quality, only four are for-profit, as in

One of the most intriguing possibili-
ties the current data facilitated was
the chance to explore the ways in
which publishers group together as
they are perceived on the key
variables of interest.

each case both the National Academy of Sciences and the Brookings Institution, which are neither university presses nor for-profit presses, also appear. One can only speculate about how many university presses would have headed the list had all such presses been included in the questionnaire.

If the dimensions on which publishers vary are considered - the academic or popular, scientific or humanistic scope of their titles, the strength of their reputations, their age and familiarity, their tendency to publish straight monographs as opposed to text books, proceedings, or edited anthologies-it is clear that publishers are not distributed evenly or randomly across the multidimensional space these attributes describe. It is not uncommon to generalize about groups of publishers, speaking of "publishers such as X and Y." 
One of the most intriguing possibilities the current data facilitated was the chance to explore the ways in which publishers group together as they are perceived on the key variables of interest. The relative simplicity of the data made it possible to do this without the strictures of a formal factor analysis. Instead, the authors inspected the correlation matrices of scores for relevance and quality to identify pairs of publishers whose perceptions co-varied, and these results were in turn examined to find larger congregations of publishers whose scores co-varied. Once the authors identified such clusters, they created new variables representing group scales. They then calculated the correlation between each cluster member and the group scale, discarded cases with weak correlations to their scales, and repeated the process.

Table 7 reports the results of this procedure for relevance scores, giving a provisional cluster name, a list of cluster members, and the mean correlation of each member to the scale. It should be noted that because each member contributes to the scale constructed for its group, a certain degree of autocorrelation is present. Generally, this is not considered problematic for larger clusters, but it presents something of a statistical artifact that artificially boosts item-to-scale correlation for smaller clusters.

Even allowing for the effects of autocorrelation, the internal coherence of the reported clusters is very high. Most observers will probably recognize commonalties among cluster members. It should be noted, however, that the labels the authors provided are purely post hoc and subjective, and it is certainly possible that others could furnish names that more accurately capture the defining characteristics of each group.

In the construction of any set of scales or clusters, the ideal outcome is relatively high covariation within groups and relative independence between groups. In addition to satisfying the first criterion, the clusters shown in table 7 did relatively well on the second. The mean correlation among scales was .32 , with none higher than .43 .

The results for quality scores were not quite so dramatic as those for relevance, reflecting a tendency of chief collection development officers to group publishers more in terms of their scope (which, within the added context of the institution's mission, translates to relevance) than in terms of quality. Nonetheless, interesting clusters emerged from an analysis of the quality scores.

\begin{tabular}{|c|c|c|c|c|}
\hline \multicolumn{5}{|c|}{$\begin{array}{l}\text { TABLE } 7 \\
\text { High Covariance Clusters for Respondent Perceptions of } \\
\text { Publisher Relevance }\end{array}$} \\
\hline $\begin{array}{c}\text { Cluster A: } \\
\text { Letters }\end{array}$ & $\begin{array}{l}\text { Cluster B: } \\
\text { Internat'l } \\
\text { Science }\end{array}$ & $\begin{array}{l}\text { Cluster } C: \\
\text { British } \\
\text { Letters }\end{array}$ & $\begin{array}{l}\text { Cluster D: } \\
\text { Commercial/ } \\
\text { Textbook }\end{array}$ & $\begin{array}{l}\text { Cluster } E \text { : } \\
\text { Library } \\
\text { Reference }\end{array}$ \\
\hline $\begin{array}{l}\text { Farrar,Straus,Giroux } \\
\text { Knopf } \\
\text { Macmillan } \\
\text { New Directions } \\
\text { New Press } \\
\text { Random House } \\
\text { Simon \& Schuster } \\
\text { Viking }\end{array}$ & $\begin{array}{l}\text { Elsevier } \\
\text { Kluwer } \\
\text { Springer } \\
\text { VCH } \\
\text { WorldScien. }\end{array}$ & $\begin{array}{l}\text { Allen \& Unwin } \\
\text { Edward Arnold } \\
\text { Ashgate }\end{array}$ & $\begin{array}{l}\text { McGraw-Hill } \\
\text { Prentice Hall } \\
\text { Van Nostrand }\end{array}$ & $\begin{array}{l}\text { Gale } \\
\text { Garland } \\
\text { Greenwood }\end{array}$ \\
\hline Mean $r=.76$ & Mean $r=.79$ & Mean $r=.88$ & Mean $r=.84$ & Mean $r=.85$ \\
\hline
\end{tabular}


TABLE 8

High Covariance Clusters for Respondent Perceptions of Publisher Quality

\begin{tabular}{|c|c|c|c|c|}
\hline $\begin{array}{c}\text { Cluster A: } \\
\text { Trade } \\
\text { Popular }\end{array}$ & $\begin{array}{l}\text { Cluster B: } \\
\text { Trade } \\
\text { Academic }\end{array}$ & $\begin{array}{l}\text { Cluster C: } \\
\text { Intn'l } \\
\text { Science } \\
\end{array}$ & $\begin{array}{l}\text { Cluster D: } \\
\text { Academic } \\
\text { Elite }\end{array}$ & $\begin{array}{c}\text { Cluster E: } \\
\text { Library } \\
\text { Reference }\end{array}$ \\
\hline $\begin{array}{l}\text { Doubleday } \\
\text { Farrar,Straus,Giroux } \\
\text { Free Press } \\
\text { HarperCollins } \\
\text { Houghton Mifflin } \\
\text { Knopf } \\
\text { Macmillan } \\
\text { McGraw-Hill } \\
\text { Prentice Hall } \\
\text { Random House } \\
\text { Simon \& Schuster } \\
\text { Viking } \\
\end{array}$ & $\begin{array}{l}\text { Addison-Wesley } \\
\text { Allen \& Unwin } \\
\text { Chapman \& Hall } \\
\text { Jossey-Bass } \\
\text { New Press } \\
\text { Routledge } \\
\text { Sharpe } \\
\text { Westview }\end{array}$ & $\begin{array}{l}\text { Academic } \\
\text { E. Arnold } \\
\text { Ashgate } \\
\text { Elsevier } \\
\text { Humanities } \\
\text { Kluwer } \\
\text { Plenum } \\
\text { Springer-Verlag }\end{array}$ & $\begin{array}{l}\text { Cambridge } \\
\text { Harvard } \\
\text { Oxford }\end{array}$ & $\begin{array}{l}\text { Gale } \\
\text { Garland } \\
\text { Greenwood }\end{array}$ \\
\hline Mean $r=.71$ & Mean $r=.70$ & Mean $r=.70$ & Mean $r=.79$ & Mean $r=.83$ \\
\hline
\end{tabular}

Table 8 represents the results in a format identical to that used in table 7 .

Not only were intracluster relationships somewhat weaker for the quality clusters than for observed relevance, there was also weaker discrimination (higher intercorrelation) among clusters. The mean correlation between pairs of clusters was .38 , compared to .32 for relevance clusters. Much of this overall strength of relationship among clusters was attributable to a .59 correlation between clusters $\mathrm{B}$ and $\mathrm{C}$. These clusters of publishers are somewhat similar in that both represent houses whose books are of a fairly serious academic nature. The difference seems to be that a higher proportion of cluster C publishers are non-U.S. houses emphasizing science. Cluster E, "Library Reference," is identical for both relevance and quality measures, indicating a fairly distinctive identity for the three "letter G" publishers which are prominent in library and reference publishing.

One of the final items on the questionnaire was an open-ended invitation for respondents to comment on the themes the study addressed. Many responded positively to this invitation or made com- ments about specific publishers. Several comments confirmed that, though not the most important factor in selecting a book, the reputation of the publisher does play a significant role. This is especially true when more concrete information may not be available, such as the reputation of the author, the existence of a review, or the ability to examine the item directly.

Several broad themes recurred throughout the comments. The most significant ones were a discussion of price (even for books that would be both highly relevant and of good quality); the importance in selection decisions of an institution's curriculum, level of instruction, and faculty research interests; the subjective nature of the selection process; and the problem of publisher specialties.

Many respondents said that the quality and relevance of an item could only be determined by including price in this consideration. Numerous comments criticized the exclusion of price as a criterion for review. With hard-pressed materials budgets, these respondents claimed, there is no determining whether an item is of good quality without considering its price. Highly relevant, good-quality items 
can and are legitimately skipped in order to stretch thin materials budgets.

Related to the consideration of price was the question of an institution's curriculum and whether it is supporting a graduate program or active faculty research. If an institution supports research by graduate students and faculty, it is more important to spend the resources to acquire and make available high-priced, high-quality research materials. The librarian has to consider the price in determining the importance of an acquisition to the overall institutional considerations, not just an item's quality and relevance to a library's collection.

Respondents mentioned many means of assessing publishers, including patterns in faculty suggestions, reviews, publisher success in winning Choice $\mathrm{OAB}$ awards, personal reading and academic preparation, and physical inspection of new receipts. As one respondent noted, "Unfortunately, no tools exist to allow selectors to evaluate systematically the quality and relevance of publishers. One of the reasons that our social science and humanities bibliographers are required to review all new acquisitions physically is that they gain a familiarity with the publishers in their areas."

\section{... the quality of a number of publishers' books varies markedly from one discipline to another.}

Many respondents believe that although relevance and quality are critical issues and do tend to vary by publisher, it is extraordinarily difficult to make valid assessments. Judgments are subjective and vary greatly from one librarian to another. Publishers are so specialized that only those familiar with a field can evaluate their work. Even so, two respondents argued, the quality of a number of publishers' books varies markedly from one discipline to another. Chance comments by individual faculty members may in- fluence a bibliographer's thoughts about a publisher for years. Other librarians may hold onto perceptions of publishers that were once the best in their fields but are now living off old reputational capital.

The remarks that several respondents made about subjectivity and about the variation in quality within the catalogs of individual publishers buttress some of the cautionary notes with which this report began. It is critical that readers of this report recognize, first, that quality is a subjective phenomenon; second, that the overall quality associated with a publisher may vary by discipline; and, finally, that even publishers considered to be weak will put out books that are widely admired. It would certainly be an abuse of the results of this study if academic committees concerned with promotion and tenure were to use its findings to assess candidates' books without reading them.

Quite a number of respondents were very candid about the difficulty of finding one person who could evaluate the entire range of publishers. Often they thought that their administrative and budgetary duties had increasingly taken them away from the substance of collection development, perhaps disqualifying them as respondents. A number indicated that they had involved several bibliographers in the rating or had delegated completion of the questionnaire to a bibliographer with less administrative responsibility, but closer daily involvement in collection-building decisions.

Several respondents shared their thoughts on different categories of publishers. One noted that books from university presses and the standard academic houses are more likely to have undergone stringent peer review. Another noted that for financial reasons university presses have begun to publish more popular material. One respondent, though noting that society publications can be very specialized and bibliographi- 
cally complex, regretted that societies such as the Institute of Electrical and Electronics Engineers (IEEE) had not been included so that they could have been compared to their commercial competitors.

Other comments made concerned the publishing industry and its many recent changes. Respondents noted that the industry has been undergoing great change, much like the library field. Several commentators stated that the lack of concern over the production of the physical book is disappointing, one thinking it may also reflect a less-thanexcellent care in intellectual content. A few respondents noted that they try to identify and purchase books on acidfree paper.

\section{Conclusion}

In addition to the main findings about collection development librarians' opinions on various publishers, this study confirms and leads to several other conclusions. That university presses are well respected is quickly confirmed, with all of them finishing in or near the top third in relevance and quality, and two-thirds of the small sample included in the survey taking the first four slots in both of these categories. Further, the study confirms that librarians tend to think of publishers in groups related around either subject scope (for relevance) or, to a lesser degree, market target (for quality). Collection de- velopment librarians clearly do have well-established mental images for publishers, images that guide both the many micro-level decisions they must make about item selection and the more critical macro-level decisions involved in such matters as the design of approval plans.

The present study is apparently the only one of its kind, and suggests a number of possibilities for replication and extension. Other dimensions of publishers' portfolios, including price, audience level, or instructional versus scholarly or scientific emphasis, could be measured. Obviously, other publishers could be included (indeed, the authors regretfully agree with one respondent who lamented the exclusion of professional societies as publishers), or similar surveys could be sent to other kinds of respondents, including academic faculty, book dealers, or publishers themselves.

Au. note: The authors wish to acknowledge gratefully Linda Southard's painstaking efforts in distributing the survey and entering the results, and the invaluable assistance of Bob Frary in instrument design and in the analysis and interpretation of their data. Readers wishing to see the questionnaire used to obtain data for this study may request a copy from the authors.

\section{Notes}

1. Hendrik Edelman, "Selection Methodology in Academic Libraries," Library Resources \& Technical Services 23 (winter 1979): 33-38.

2. Charles A. Schwartz, "Book Selection and Bounded Rationality," College \& Research Libraries 50 (May 1989): 328-43.

3. John Calhoun and James K. Bracken, "An Index of Publisher Quality for the Academic Library," College \& Research Libraries 44 (May 1983): 257-59.

4. Edward A. Goedeken, "An Index to Publisher Quality Revisited: A Partial Replication," Library Acquisitions: Practice \& Theory 17 (fall 1993): 263-68 .

5. Two printing errors should be reported. On the questionnaire sent out in the first mailing, Edwin Mellen was represented as "Edward Mellen" and the " 5 " score for quality of Stanford University Press was omitted. These errors were corrected for the second mailing. Many respondents provided their own " 5 " for Stanford's quality score, then circled it. The differences in scores for these publishers were not statistically significant between the two versions. In both, Stanford ranked fourth and Mellen last on quality. Stanford's quality scores closely co-vary with its relevance scores, for which there was no omission. 


\section{INFORMATION COMES IN ALL}

\section{SHAPES AND SIZES}

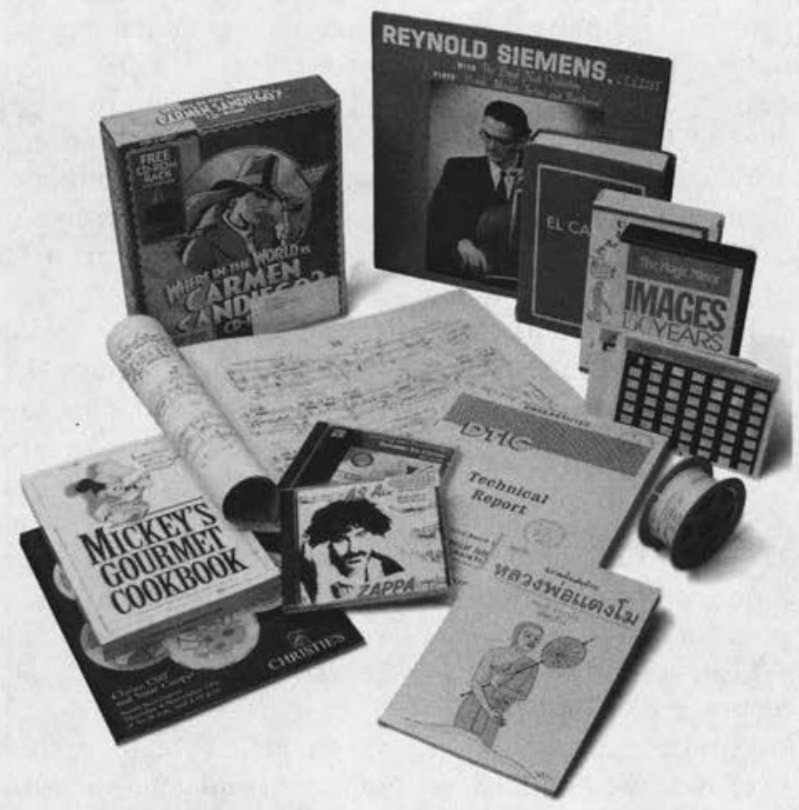

\section{OCLC's TECHPRO Service catalogs it all}

With library resources so stretched, it's challenging to keep your cataloging upto-date. And it's frustrating, because uncataloged materials are inaccessible to your patrons.

OCLC's TECHPRO Service can help. Since 1985, we've offered solutions for libraries that have cataloging backlogs or need ongoing cataloging support.

- Customized cataloging and physical processing to match your specifications

- Cataloging for all bibliographic formats and many languages

- Quality cataloging at prices that can reduce your overall cataloging costs

Contract cataloging for books, serials, scores, non-print items, foreign language materials and more-it's cataloging in all shapes and sizes-from OCLC's TECHPRO Service.

1-800-848-5878, ext. 4386

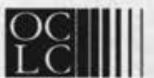

